\title{
Rock Anelasticity Studies at High Pressure and Temperature
}

\author{
Hiroki SATO*
}

\begin{abstract}
Geophysical techniques used in the exploration for the thermal structure of the Earth include heat flow measurements, seismic studies and electric and electromagnetic soundings. The goals of these geophysical explorations are to detect and interpret the anomalies defined in the physical quantities measured, and to derive thermal models of the Earth. To this end, knowledge of the physical properties of in-situ rocks is required.

In particular, seismic methods, which provide the most direct definitive information, have the maximum potential for probing high temperature and partial melt in the Earth. Thus, from the standpoint of successful seismic exploration, an understanding of the seismic properties of rocks is an important requisite. The parameters of direct interest here are the seismic velocity and attenuation $\left(Q^{-1}\right)$; the variables are pressure, temperature, frequency, fluid content, chemical composition (including volatile content), grain size and preferred mineral orientation.

It is anticipated that laboratory anelasticity data are valuable for the interpretation of seismic structure in terms of composition, temperature, and the degree of fluid or partial melt under regions where high attenuation (low $Q$ ) has been reported. The laboratory results are particularly applied to the locations of geophysical interest, the midocean ridge, the hot spot and the island arc, where seismic models have been extensively studied.

The recent progress in anelasticity study shows that the low $Q$ asthenosphere beneath ocean basins is hot but solid, and that seismic wave absorption mostly occurs at the mineral grain boundaries. Partial melt exists only in the extremely low $Q$ zones right beneath ocean ridges or hot spots. For island arc volcanism, the descending slab is thought to be a possible source of volatiles. A role of volatiles in arc volcanism will be investigated from laboratory $Q$ studies on hydrous rocks.
\end{abstract}

Key words : low $Q$, grain boundary damping, grain size dependence, weak frequency dependence, volatile effect

* Department of Earth and Space Science, Osaka University, Toyonaka, Osaka 560-0043, Japan 


\section{Introduction}

In order to relate elasticity and anelasticity of the Earth as determined by seismologists to physical parameters such as temperature and degree of melt, the velocity and attenuation in rocks have been determined in the laboratory. Because of the technical difficulty, the pressure effect on the seismic properties of rocks has initially been ignored at high temperatures. In earlier studies, most seismic measurements were carried out as a function of temperature at one atmosphere (Woirgard and Guéguen, 1978; Berckhemer et al., 1982; Sacks and Murase, 1983; Kampfmann and Berckhemer, 1985; Sato and Manghnani, 1985; Manghnani et al., 1986), or as a function of pressure at room temperature (Toksöz et al., 1979; Katahara et al., 1982; Jackson et al., 1984; Carlson and Gangi, 1985). A small number of velocity measurements were made for mantle rocks at high pressure and relatively low temperatures (below $1000^{\circ} \mathrm{C}$ ) compared to the upper mantle conditions (Spetzler et al., 1969; Spetzler, 1970; Matsushima, 1972; Matsushima and Akeni, 1977; Fukizawa and Kinoshita, 1982).

Until recently, the studies by Murase and Kushiro (1979) and Murase and Fukuyama (1980), showing velocity drops as a function of melt fraction, were the only available data sources for velocities measured above the solidus of peridotites with high confining pressure (to $1 \mathrm{GPa}$ ). Anelastic properties of a peridotite were investigated, for the first time, by Sato et al. (1988a, b, 1989b) at high temperatures and 0.2-0.73 GPa confining pressures. These previous studies have measured velocity and attenuation at temperatures including both the sub- and hyper-solidus of the upper mantle rocks. Therefore, effects of partial melting on seismic properties were studied.
Their results indicate that partial melt does not produce any abrupt change in velocity and $Q$, rather elastic and anelastic properties of the upper mantle change gradually at the boundary where the geotherm crosses the solidus.

No frequency dependence of $Q$ in peridotite was resolved from 60 to $880 \mathrm{kHz}$ by Sato et al. (1989b), owing to the uncertainty in spectral ratio technique by means of analogue equipments in those days. A weak frequency dependence of seismic $Q$ has been determined in the laboratory (e.g., Nur and Winkler, 1980; Kampfmann and Berckhemer, 1985; Jackson and Paterson, 1987; Jackson et al., 1992, 2002; Gribb and Cooper, 1998) and in the Earth by seismic study (e.g., Sipkin and Jordan, 1979; Anderson and Given, 1982; Ulug and Berckhemer, 1984; Romero et al., 1997; Haberland and Rietbrock, 2001; Gudmundsson et al., 2004).

Sato et al. (1989b) pointed out that $Q$ determined by means of an ultrasonic technique is comparable to seismic $Q$ observed in the upper mantle. Their results indicate a wide distribution of relaxation frequencies in a peridotite, or higher relaxation frequencies due to smaller grain sizes in the laboratory than in the upper mantle. Their results have, therefore, noted that the study on the effects of grain size and frequency on $Q$ in peridotite may reveal the mechanism of seismic wave absorption in the upper mantle. This study would also allow the extrapolation of the laboratory data to larger grain sizes found in the upper mantle. Until recently, effects of grain size on seismic measurements have not been investigated at high pressure and temperature. At one atmosphere and high temperature, Kampfmann and Berckhemer (1985) determined $Q$ in gabbro of various grain size $\left(0.25^{-}\right.$ 
$1 \mathrm{~mm}$ ). In their study, however, a real grainsize dependence of $Q$ may not be separated from the effect of cracks on $Q$, since the high pressure, to close cracks, is not applied to the sample. Lately, Tan et al. (2001) and Jackson et al. (2002, 2004) studied $Q$ as a function of grain size and frequency at high pressure and temperature.

Here I briefly review the recent progress and the future perspectives of the laboratory anelasticity studies. A comprehensive review of seismic measurements and temperature estimates for low velocity and low $Q$ zones studied before the mid 1990's was given by Sato (1995). Experimental techniques and results of rock anelasticity measurements have been reviewed by Jackson (1993, 2000).

\section{Attenuation Mechanism}

Influence of partial melting on seismic properties of rocks has been a fundamental problem in the Earth sciences. The model of partially molten upper mantle has long been discussed as the cause of the asthenosphere. However, a real mechanism of seismic wave absorption in the asthenosphere was not well known. Previous studies have shown the importance of partial melting, viscous grain boundary and dislocation motion for the attenuation (Jackson and Anderson, 1970; Guéguen and Mercier, 1973). A mechanism involving dislocations (Woirgard and Guéguen, 1978; Minster and Anderson, 1980; Anderson and Minster, 1981; Guéguen et al., 1981) or grain boundaries (Jackson, 1969; Goetze, 1977; O'Connell and Budiansky, 1977) has been proposed as a possible explanation for the low $Q$ asthenosphere. If the relaxation frequency is observed within the frequency range of the laboratory measurement, this observation strongly constrains the mechanism of the at- tenuation. For this purpose, laboratory studies should cover as wide frequency as possible.

Karato and Spetzler (1990) pointed out that dislocation and/or grain boundary mechanisms can have a significant effect on seismic wave propagation. Since the dislocation density and the grain size reflect the long-term tectonic stress, seismic wave attenuation and velocity dispersion are likely to depend on the magnitude of the tectonic stress as well as the temperature. In most experimental studies before 1990, however, the dislocation density or the grain size was not well controlled, making it difficult to identify the attenuation mechanism and preventing any quantitative applications to the Earth. The need for better characterization of defect microstructures in experimental study is emphasized by Karato and Spetzler (1990).

Jackson and Paterson (1987) measured shear modulus and internal friction of calcite rocks in the frequency range of 0.0033 to 1 $\mathrm{Hz}$ at $0-300 \mathrm{MPa}$. They observed that increase in pressure to about $100 \mathrm{MPa}$ results in a marked increase in shear modulus and decrease in internal friction, indicating the closure of crack porosity. At higher pressures, shear modulus is much less pressure-sensitive and internal friction is pressure-independent with values less than 0.001 . Within the pressure-independent regime, internal friction is also independent of frequency, and increases by only $30 \%$ as the grain size decreases from $1 \mathrm{~mm}$ to $4 \mu \mathrm{m}$. It is therefore concluded that internal friction of calcite rocks results from an intracrystalline mechanism involving dislocation damping with a broad range of relaxation times.

Jackson et al. (1992) measured anelasticity of Åheim dunite to $1000{ }^{\circ} \mathrm{C}$ and $300 \mathrm{MPa}$ over a seismic frequency range from 0.01 to 
$1 \mathrm{~Hz}$ and a low strain amplitude from $10^{-8}$ to $10^{-6}$. At $300 \mathrm{MPa}$ and $1000^{\circ} \mathrm{C}$, up to $5 \%$ dispersion of the shear modulus and strong internal friction varying with frequency as $f^{-1 / 6}$ are observed. The energy dissipation appears to be concentrated within the olivine grains, indicating that intragranular anelastic relaxation in ultramafic rocks gives rise to losses comparable with those observed seismologically in the Earth's upper mantle. Their specimen shows strong anelastic relaxation under subsolidus conditions. The results suggest that it is not necessary to invoke the presence of melt to explain the low shear wave velocities and intense attenuation commonly observed in the upper mantle asthenosphere.

Sato et al. (1989b) proposed the model of grain boundary damping as the cause of the high attenuation in the upper mantle. They suggest that attenuation in peridotite can be controlled by grain boundary relaxation as described by $\mathrm{Ke}$ (1947, 1949) and Mosher et al. (1976). According to $\mathrm{Ke}$ (1947), relaxation frequency of $Q$ is inversely proportional to the grain size. Therefore, it was pointed out that the study on the grain-size dependence of $Q$ may be used to constrain attenuation mechanism in peridotite.

Many recent studies adopt absorption mechanisms activated at the grain boundaries (e.g., Gribb and Cooper, 1998; Tan et al., 2001; Jackson et al., 2002; Faul et al., 2004). Those studies used fine-grained synthetic aggregates for elastic, anelastic and viscoelastic property measurements, because fine grains have the advantages of chemical homogeneity, controlled purity and microstructure, and resistance to thermal cracking (Jackson, 2000). Jackson (2000) reported that iron alloy, olivine and $\mathrm{CaTiO}_{3}$-perovskite polycrystals show increases of dissipation and associated shear modulus dispersion with increasing temperature and decreasing frequency, due to the loss of seismic energy at the grain boundaries.

Attenuation in a fine-grained olivine aggregate was first studied in torsion at high temperature and seismic frequency by Gribb and Cooper (1998). They argued that Andrade creep function fits to the creep and attenuation behavior of the olivine polycrystal, having the modest frequency dependence of $Q$ as $Q \propto f^{0.35}$. Diffusional processes at the grain boundaries are suggested for absorption mechanism in their olivine and in the upper mantle.

$Q$ in fine-grained polycrystalline olivine was further studied to $1300{ }^{\circ} \mathrm{C}$ at $200 \mathrm{MPa}$ and seismic frequency by Tan et al. (2001). Their hot-pressed samples (less than $2 \%$ porosity) were first annealed at $1300{ }^{\circ} \mathrm{C}$ for $7-47$ hours, and measurements were carried out at successive cooling from $1300{ }^{\circ} \mathrm{C}$ to room temperature. Both shear modulus and $Q$ in olivine increased with increasing annealing time, and eventually shear modulus approached the modulus of single crystal olivine. Their hightemperature results are expressed as $Q \propto$ $A d^{m} f^{\alpha} \exp (\alpha E / R T)$, with $\alpha=0.22-0.31, E$ $=410-508 \mathrm{~kJ} / \mathrm{mol}$ and $m=0-0.5$ for $8-150$ $\mu \mathrm{m}$ grain size, where $d$ is grain size, $f$ is frequency, $E$ is activation energy, $R$ is gas constant, $T$ is temperature, and $A, m$ and $\alpha$ are constant. Therefore, $Q$ is grain-size sensitive, and grain-boundary sliding is suggested for the cause of anelastic and viscoelastic properties of the polycrystalline olivine.

Further, shear attenuations in four olivine polycrystals ranging in mean grain-size from 3 to $23 \mu \mathrm{m}$ were extensively studied by Jackson et al. (2002). At $1000-1300^{\circ} \mathrm{C}, 0.01-1 \mathrm{~Hz}$ and $200 \mathrm{MPa}, Q$ is expressed as $Q=A[d f \exp$ $(E / R T)]^{\alpha}$, where $\alpha$ is 0.26 and $E$ is $424 \mathrm{~kJ} /$ 
mol. Extrapolations of their subsolidus results to upper mantle conditions give $Q$ values comparable to seismic observations. Therefore, much of seismic wave attenuation in the asthenosphere (excluding right beneath the ridges) is attributed to grain boundary sliding in the absence of melt.

\section{Effect of Partial Melt and Grain Size}

By studying the variation of $Q$ with melt fraction, frequency, temperature and grain size in olivine-basalt melt system, Jackson et al. (2004) observed a broad absorption peak, that was not detected in melt-free olivine polycrystals in the same frequency, temperature and grain-size range. The broad peak was a robust feature even for a small melt fraction $(0.4 \%)$. Attenuation mechanism causing the broad peak was investigated by Faul et al. (2004). Their examinations of olivine-olivine grain boundaries by SEM, TEM and EDS and estimates of relaxation frequencies indicate grain-boundary sliding, not melt, as the cause of the attenuation peak. They note that the observed relaxation frequencies $(\sim 1 \mathrm{~Hz})$ differ in several orders of magnitude from those of melt squirt model described by Mavko and Nur (1975). Extrapolations of their laboratory results to upper mantle grain sizes indicate that the broad peak may be responsible for nearly frequency independent attenuation in partially molten regions of the upper mantle. The extrapolations also suggest low melt fractions $(0.1 \%)$ in average through relatively large regions ( $>200 \mathrm{~km}$ horizontally) for $Q$ models beneath hotspots and ridges, that may include both partially molten and melt-free mantle. The idea of small amount of melt is consistent with the melt fraction estimated by Sato and Sacks (1989, 1990) and Sato et al. (1989a, 1998, 2003), showing that zones of partial melting are localized in the asthenosphere right beneath the ocean ridges.

Further, mantle seismic structures are compared with velocity and attenuation in olivine aggregates measured as a function of temperature and grain size by Faul and Jackson (2005), to study variations of temperature and grain size in the upper mantle. The comparison of laboratory data by Tan et al. (2001) and Jackson et al. (2002) with seismic models again indicates the low velocity and low $Q$ zones beneath oceans to be subsolidus hightemperature (no melt) regions. While relatively large velocity variations in the upper mantle $(<200 \mathrm{~km}$ depth $)$ are explained by temperature differences, the velocity increase at $>200 \mathrm{~km}$ depth indicates an increase in grain size from order of $\mathrm{mm}$ to $\mathrm{cm}$ (Faul and Jackson, 2005).

\section{Future Perspectives}

Laboratory anelasticity measurements are scarce, and too little to constrain the attenuation mechanism and the mechanical properties of the Earth. Further investigations are necessary to allow the comparison of laboratory results with field seismic data. The previous attenuation measurements on, e.g., mantle rocks are limited for dry peridotites or synthetic olivine polycrystals. No systematic laboratory investigations are ever made for the effects of volatiles $\left(\mathrm{H}_{2} \mathrm{O}\right.$ and/or $\left.\mathrm{CO}_{2}\right)$ on seismic properties at high pressure and temperature. The solidus temperatures of rocks are largely reduced by the presence of volatiles (e.g., Kushiro et al., 1968; Millhollen et al., 1974; Ringwood, 1975; Wyllie, 1979; Thompson, 1992; Schmidt and Poli, 1998; Litasov and Ohtani, 2002; Kawamoto, 2004). Seismic properties of rocks may strongly depend on volatile contents. It is interesting to study if 
Q-homologous temperature relation observed in dry peridotite by Sato et al. (1989b) will also be confirmed in hydrous peridotite. A role of volatiles in the Earth needs to be investigated from laboratory and seismic $Q$ data.

The torsion technique as developed by Australian National University group is a powerful tool to study shear velocity $\left(V_{s}\right)$ and attenuation $\left(Q_{s}^{-1}\right)$ at seismic frequencies (e.g., Jackson, 2000). However, the technique does not allow one to determine $\mathrm{P}$-wave properties $\left(V_{p}\right.$ and $\left.Q_{p}\right)$, and is currently limited to relatively low pressure range $(<0.3 \mathrm{GPa})$.

At higher pressures to $0.6 \mathrm{GPa}$ by means of ultrasonic techniques, Kern at University of Kiel, Germany and his colleagues measured $Q_{p}$ and $Q_{s}$ as well as $V_{p}$ and $V_{s}$ simultaneously in serpentinite and amphibolite (Kern et al., 1997), and in granite, graywacke and sandstone (Liu et al., 1997). Kern et al. (1997) also reported S-wave splitting along the three orthogonal directions of the cubic samples at pressures to $0.6 \mathrm{GPa}$ and temperatures to $700^{\circ} \mathrm{C}$. Therefore, they reported nine velocity and nine attenuation data, that is, velocity anisotropy, $Q$ anisotropy, acoustic birefringence, $V_{p} / V_{s}$ ratio and $Q_{p} / Q_{s}$ ratio; all of them corresponding to seismic properties of one single rock sample. Velocity anisotropy that is caused by both the oriented microcracks and the lattice preferred orientation of antigorite or hornblend decreases with increasing pressure owing to the closure of microcracks (Kern et al., 1997). On the other hand, anisotropy of $Q$ in serpentinite and amphibolite is low at low pressure and enhanced as pressure is increased. At high pressure, $Q_{p}$ is highest in the direction normal to the foliation plane, whereas $V_{p}$ and $V_{s}$ are generally lowest in the same direction. Closure of oriented microcracks and increase of contact areas in be- tween the grain boundaries along the foliation are suggested for the reason of the highest $Q_{p}$ (Kern et al., 1997). Anisotropy increase in $Q_{p}$ at high pressure is observed in their study, and attributed to a directional dependent decrease of open cracks.

A full understanding of rock anelasticity has to await further laboratory measurements at the conditions of the upper mantle (above 1 GPa and high temperature). Recently, Sato et al. (2004) have developed the method of simultaneous velocity and attenuation measurements at high pressure and temperature. By observing both the direct and reflected echoes, pulse overlap and spectral ratio techniques are conveniently used to determine intrinsic sample properties and to eliminate unknown extrinsic effects, such as buffer rod properties, assembly geometries and frequency characteristics of transducers and instruments being common to both echoes (Sato et al., 2004). In situ measurements of travel time and spectral amplitude of echoes transmitted only within the sample are essential for determining accurate velocity and attenuation simultaneously at high pressure and temperature. The high acoustic impedance of platinum is suitable as a buffer rod for observing both the direct and reflected echoes, and so for determining intrinsic properties, of various samples of ceramics, minerals, glasses and light metals. By using platinum rods, Sato et al. (2004) determined compressional-wave velocity and attenuation in fused silica at $1 \mathrm{GPa}$ and temperatures to $1200{ }^{\circ} \mathrm{C}$. Their measured velocities were consistent with the values reported earlier. In general, the acoustic impedance of platinum is much higher than that of ceramics, minerals, rocks, glasses and light metals. Therefore, their method should be applicable to velocity and attenuation measurements for various sol- 
ids at high pressures and temperatures. Velocity and $Q$ measurements at pressures to 3 $\mathrm{GPa}$ and temperatures to $1300^{\circ} \mathrm{C}$ are currently underway by Sato et al. (2005).

\section{Acknowledgments}

The author thanks Prof. Nishizawa for giving the opportunity to contribute to this volume. This work was supported by grants from JSPS (C15540459), and from the Earthquake Research Institute of the University of Tokyo (2005-A-14).

\section{References}

Anderson, D.L. and Given, J.W. (1982): Absorption band Q model for the earth. J. Geophys. Res., 87, 3893-3904.

Anderson, D.L. and Minster, J.B. (1981): The physics of creep and attenuation in the mantle. In Stacey, F.D., Paterson, M.S. and Nicholas, A. eds.: Anelasticity in the Earth. Amer. Geophys. Union, 511.

Berckhemer, H., Kampfmann, W., Aulbach, E. and Schmeling, H. (1982): Shear modulus and Q of forsterite and dunite near partial melting from forced-oscillation experiments. Phys. Earth Planet. Inter., 29, 30-41.

Carlson, R.L. and Gangi, A.F. (1985): Effect of cracks on the pressure dependence of $p$ wave velocities in crystalline rocks. J. Geophys. Res., 90, 8675-8684.

Faul, U.H. and Jackson, I. (2005): The seismological signature of temperature and grain size variations in the upper mantle. Earth Planet. Sci. Lett., 234, 119-134.

Faul, U.H., Fitz Gerald, J.D. and Jackson, I. (2004): Shear wave attenuation and dispersion in meltbearing olivine polycrystals: 2. Microstructural interpretation and seismological implications. $J$. Geophys. Res., 109, B06202, doi:10.1029/2003JB 002407.

Fukizawa, A. and Kinoshita, H. (1982): Shear wave velocity jump at the olivine-spinel transformation in $\mathrm{Fe}_{2} \mathrm{SiO}_{4}$ by ultrasonic measurements in situ. $J$. Phys. Earth, 30, 245-253.

Goetze, C. (1977): A brief summary of our present day understanding of the effect of volatiles and partial melt on the mechanical properties of the upper mantle. In Manghnani, M.H. and Akimoto, S. eds.: High Pressure Research: Applications in Geophysics. Academic Press, 3-23.

Gribb, T.T. and Cooper, R.F. (1998): Low-frequency shear attenuation in polycrystalline olivine: Grain boundary diffusion and the physical significance of the Andrade model for viscoelastic rheology. $J$. Geophys. Res., 103, 27267-27279.

Gudmundsson, O., Finlayson, D.M., Itikarai, I., Nishimura, Y. and Johnson, W.R. (2004): Seismic attenuation at Rabaul volcano, Papua New Guinea. J. Volcano. Geotherm. Res., 130, 77-92.

Guéguen, Y. and Mercier, J.M. (1973): High attenuation and the low-velocity zone. Phys. Earth Planet. Inter., 7, 39-46.

Guéguen, Y., Woirgard, J. and Darot, M. (1981): Attenuation mechanisms and anelasticity in the upper mantle. In Stacey, F.D., Paterson, M.S. and Nicholas, A. eds.: Anelasticity in the Earth. Amer. Geophys. Union, 86-94.

Haberland, C. and Rietbrock, A. (2001): Attenuation tomography in the western central Andes: A detailed insight into the structure of a magmatic arc. J. Geophys. Res., 106, 11151-11167.

Jackson, D.D. (1969): Elastic relaxation model for seismic wave attenuation in the earth. Phys. Earth Planet. Inter., 2, 30-34.

Jackson, I. (1993): Progress in the experimental study of seismic wave attenuation. Ann. Rev. Earth Planet. Sci., 21, 375-406.

Jackson, I. (2000): Laboratory measurement of seismic wave dispersion and attenuation: Recent progress. In Karato, S., Forte, A.M., Liebermann, R.C., Masters, G. and Stixrude, L. eds.: Earth's Deep Interior: Mineral Physics and Tomography from the Atomic to the Global Scale. Amer. Geophys. Union, 265-289.

Jackson, D.D. and Anderson, D.L. (1970): Physical mechanisms of seismic-wave attenuation. Rev. Geophys., 8, 1-63.

Jackson, I. and Paterson, M.S. (1987): Shear modulus and internal friction of calcite rocks at seismic frequencies: Pressure, frequency and grain size dependence. Phys. Earth Planet. Inter., 45, 349-367.

Jackson, I., Paterson, M.S., Niesler, H. and Waterford, R.M. (1984): Rock anelasticity measurements at high pressure, low strain amplitude and seismic frequency. Geophys. Res. Lett., 11, 1235-1238.

Jackson, I., Paterson, M.S. and Fitz Gerald, J.D. (1992): Seismic wave dispersion and attenuation in Åheim dunite: An experimental study. Geophys. J. Int., 108, 517-534.

Jackson, I., Fitz Gerald, J.D., Faul, U.H. and Tan, B.H. (2002): Grain-size-sensitive seismic wave attenuation in polycrystalline olivine. J. Geophys. Res., 107, 2360, doi:10.1029/2001JB001225.

Jackson, I., Faul, U.H., Fitz Gerald, J.D. and Tan, B.H. (2004): Shear wave attenuation and dispersion in melt-bearing olivine polycrystals: 1 . Specimen fabrication and mechanical testing. J. Geophys. Res., 109, B06201, doi:10.1029/2003JB002406.

Kampfmann, W. and Berckhemer, H. (1985): High temperature experiments on the elastic and an- 
elastic behavior of magmatic rocks. Phys. Earth Planet. Inter., 40, 223-247.

Karato, S. and Spetzler, H.A. (1990): Defect microdynamics in minerals and solid-state mechanisms of seismic wave attenuation and velocity dispersion in the mantle. Rev. Geophys., 28, 399-421.

Katahara, K.W., Manghnani, M.H., Devnani, N. and Tittmann, B.R. (1982): Pressure dependence of Q in selected rocks. In Akimoto, S. and Manghnani, M.H. eds.: High-Pressure Research in Geophysics, Adv. Earth Planet. Sci., Vol. 12. Center for Acad. Publ. Japan, 147-158.

Kawamoto, T. (2004): Hydrous phase stability and partial melt chemistry in $\mathrm{H}_{2} \mathrm{O}$-saturated $\mathrm{KLB}-1$ peridotite up to the uppermost lower mantle conditions. Phys. Earth Planet. Inter., 143-144, 387395.

Ke, T.S. (1947): Experimental evidence of the viscous behavior of grain boundaries in metals. Phys. Rev., 71, 533-546.

Ke, T.S. (1949): A grain boundary model and the mechanism of viscous intercrystalline slip. J. Appl. Phys., 20, 274-280.

Kern, H., Liu, B. and Popp, T. (1997): Relationship between anisotropy of $\mathrm{P}$ and $\mathrm{S}$ wave velocities and anisotropy of attenuation in serpentinite and amphibolite. J. Geophys. Res., 102, 3051-3065.

Kushiro, I., Syono, Y. and Akimoto, S. (1968): Melting of a peridotite nodule at high pressures and high water pressures. J. Geophys. Res., 73, 60236029 .

Litasov, K. and Ohtani, E. (2002): Phase relations and melt compositions in CMAS-pyrolite- $\mathrm{H}_{2} \mathrm{O}$ system up to $25 \mathrm{GPa}$. Phys. Earth Planet. Inter., 134, 105-127.

Liu, B., Kern, H. and Popp, T. (1997): Attenuation and velocities of $\mathrm{P}$ - and S-waves in dry and saturated crystalline and sedimentary rocks at ultrasonic frequencies. Phys. Chem. Earth, 22, 75-79.

Manghnani, M.H., Sato, H. and Rai, C.S. (1986): Ultrasonic velocity and attenuation measurements on basalt melts to $1500^{\circ} \mathrm{C}$ : Role of composition and structure in the viscoelastic properties. $J$. Geophys. Res., 91, 9333-9342.

Matsushima, S. (1972): Compressional wave velocity in olivine nodules at high pressure and temperature. J. Phys. Earth, 20, 187-195.

Matsushima, S. and Akeni, K. (1977): Elastic wave velocities in the Ichinomegata ultramafic nodules: Composition of the uppermost mantle. In Manghnani, M.H. and Akimoto, S. eds.: High Pressure Research: Applications in Geophysics. Academic Press, 65-76.

Mavko, G. and Nur, A. (1975): Melt squirt in asthenosphere. J. Geophys. Res., 80, 1444-1448.

Millhollen, G.L., Irving, A.J. and Wyllie, P.J. (1974): Melting interval of peridotite with 5.7 percent wa- ter to 30 kilobars. J. Geol., 82, 575-587.

Minster, J.B. and Anderson, D.L. (1980): Dislocations and nonelastic processes in the mantle. J. Geophys. Res., 85, 6347-6352.

Mosher, D.R., Raj, R. and Kossowsky, R. (1976): Measurement of viscosity of the grain-boundary phase in hot-pressed silicon nitride. J. Mater. Sci., 11, 49-53.

Murase, T. and Fukuyama, H. (1980): Shear wave velocity in partially molten peridotite at high pressures. Carnegie Inst. Wash. Year Book, 79, 307-310.

Murase, T. and Kushiro, I. (1979): Compressional wave velocity in partially molten peridotite at high pressures. Carnegie Inst. Wash. Year Book, 78, 559-562.

Nur, A. and Winkler, K. (1980): The role of friction and fluid-flow in wave attenuation in rocks. Geophysics, 45, 591-592.

O'Connell, R.J. and Budiansky, B. (1977): Viscoelastic properties of fluid-saturated cracked solids. $J$. Geophys. Res., 82, 5719-5735.

Ringwood, A.E. (1975): Composition and Petrology of the Earth's Mantle. McGraw-Hill.

Romero, A.E., McEvilly, T.V. and Majer, E.L. (1997): 3-D microearthquake attenuation tomography at the Northwest Geysers geothermal region, California. Geophysics, 62, 149-167.

Sacks, I.S. and Murase, T. (1983): The anelasticity of peridotite and partial melt in the asthenosphere. Carnegie Inst. Wash. Year Book, 82, 509512.

Sato, H. (1995): Laboratory seismic studies: A search for mechanical, thermal and chemical structures of the earth. J. Phys. Earth, 43, 421455.

Sato, H. and Manghnani, M.H. (1985): Ultrasonic measurements of $\mathrm{Vp}$ and $\mathrm{Qp}$ : Relaxation spectrum of complex modulus on basalt melts. Phys. Earth Planet. Inter., 41, 18-33.

Sato, H. and Sacks, I.S. (1989): Anelasticity and thermal structure of the oceanic upper mantle: Temperature calibration with heat flow data. $J$. Geophys. Res., 94, 5705-5715.

Sato, H. and Sacks, I.S. (1990): Magma generation in the upper mantle inferred from seismic measurements in peridotite at high pressure and temperature. In Ryan, M.P. ed.: Magma Transport and Storage. John Wiley \& Sons, 277-292.

Sato, H., Sacks, I.S., Takahashi, E. and Scarfe, C.M. (1988a): Geotherms in the Pacific Ocean from laboratory and seismic attenuation studies. Nature, 336, 154-156.

Sato, H., Sacks, I.S., Murase, T., Muncill, G.E. and Fukuyama, H. (1988b): Attenuation of compressional waves in peridotite measured as a function of temperature at $200 \mathrm{MPa}$. Pure Appl. Geophys., 
128, 433-447.

Sato, H., Sacks, I.S. and Murase, T. (1989a): The use of laboratory velocity data for estimating temperature and partial melt fraction in the lowvelocity zone: Comparison with heat flow and electrical conductivity studies. J. Geophys. Res., 94, 5689-5704.

Sato, H., Sacks, I.S., Murase, T., Muncill, G.E. and Fukuyama, H. (1989b): Qp-melting temperature relation in peridotite at high pressure and temperature: Attenuation mechanism and implications for the mechanical properties of the upper mantle. J. Geophys. Res., 94, 10647-10661.

Sato, H., Muro, K. and Hasegawa, A. (1998): Threedimensional mapping of magma source and transport regions from seismic data: The mantle wedge beneath northeastern Japan. Pure Appl. Geophys., 153, 377-398.

Sato, H., Muro, K, Hasegawa, A. and Zhao, D. (2003): Mathematica as a powerful and practical tool for displaying animated three-dimensional structures of the earth's interior. Geochem. Geophys. Geosyst., 4, 1034, doi:10.1029/2001GC000303.

Sato, H., Ito, K. and Aizawa, Y. (2004): Simultaneous velocity and attenuation measurements applicable to various solids at high pressures and temperatures up to $1200^{\circ} \mathrm{C}$. Meas. Sci. Technol., 15, 1787-1793.

Sato, H., Ito, K. and Kanazawa, H. (2005): Velocity and $\mathrm{Q}$ measurements at high pressure and temperature using a large-volume cylinder. The Joint Meeting of Earth and Planetary Science, 2005 Joint Meeting, Chiba, Japan, I019P-001.

Schmidt, M.W. and Poli, S. (1998): Experimentally based water budgets for dehydrating slabs and consequences for arc magma generation. Earth Planet. Sci. Lett., 163, 361-379.

Sipkin, S.A. and Jordan, T.H. (1979): Frequency dependence of Qscs. Bull. Seismo. Soc. Amer., 69, 1055-1079.

Spetzler, H. (1970): Equation of state of polycrystalline and single-crystal $\mathrm{MgO}$ to 8 Kilobars and 800 K. J. Geophys. Res., 75, 2073-2087.

Spetzler, H., Newbigging, D. and Schreiber, E. (1969): Coupling of ultrasonic energy through lapped surfaces at high temperature and pressure. J. Acoust. Soc. Amer., 45, 1057-1058.

Tan, B.H., Jackson, I. and Fitz Gerald, J.D. (2001): High-temperature viscoelasticity of fine-grained polycrystalline olivine. Phys. Chem. Minerals, 28, 641-664.

Thompson, A.B. (1992): Water in the earth's upper mantle. Nature, 358, 295-302.

Toksöz, M.N., Johnston, D.H. and Timur, A. (1979): Attenuation of seismic waves in dry and saturated rocks: I. Laboratory measurements. Geophysics, 44, 681-690

Ulug, A. and Berckhemer, H. (1984): Frequency dependence of $\mathrm{Q}$ for seismic body waves in the earth's mantle. J. Geophys., 56, 9-19.

Woirgard, J. and Guéguen, Y. (1978): Elastic modulus and internal friction in enstatite, forsterite and peridotite at seismic frequencies and high temperatures. Phys. Earth Planet. Inter., 17, 140146.

Wyllie, P.J. (1979): Magmas and volatile components. Amer. Mineral., 64, 469-500.

(Received, September 22, 2005; Accepted, November 17, 2005) 


\section{高温高圧における岩石の非弾性研究}

佐 藤 博 樹*

地球内部温度構造を調べる地球物理学的手法に, 地殼熱流量の測定や地震学的手法, また電磁気学 的な観測手法がある。これら物理探查の目的は観 測量の異常を検出し, また異常の原因を解明し, 地球の熱モデルを構築することにある。とりわけ, 地震学的手法は地球内部の高温と部分溶融量を見 積もるのに最も強力な手段を提供するので, 岩石 の地震波速度と減衰係数 $\left(Q^{-1}\right)$ を実験室にて高 温高圧下で決定したい。コントロールする変数は 温度, 圧力, 周波数, 化学組成, 流体量, 結晶粒 径と鉱物の格子選択配向である。特に高減衰（低 Q）が報告される海洋中央海嶺やホットスポット,
また島弧下の組成や温度，流体量を見積もる際に， 実験室の非弾性デー夕は大変有力な手段となる。

近年の地球内部構成物質に関する非弾性研究に より，海洋下の低 $Q$ アセノスフェアは一般に高温 であるがメルトを含まず，地震波の減衰は主に鉱 物結晶粒界で起きていることが明らかとなってき た。部分溶融は海嶺やホットスポット直下の顕著 な低 $Q$ 層にのみ存在する。また，島弧では沈み込 むスラブが揮発性成分の供給源と考えられ，島弧 火山活動に扔ける揮発性成分の役割について，今 後, 含水鉱物や含水岩石に関する $Q$ 值の研究から 明らかにする必要がある。

キーワード：低 $Q$, 粒界減衰, 粒径依存性, 弱い周波数依存性, 揮発性成分の効果

* 大阪大学大学院理学研究科宇宙地球科学専攻 